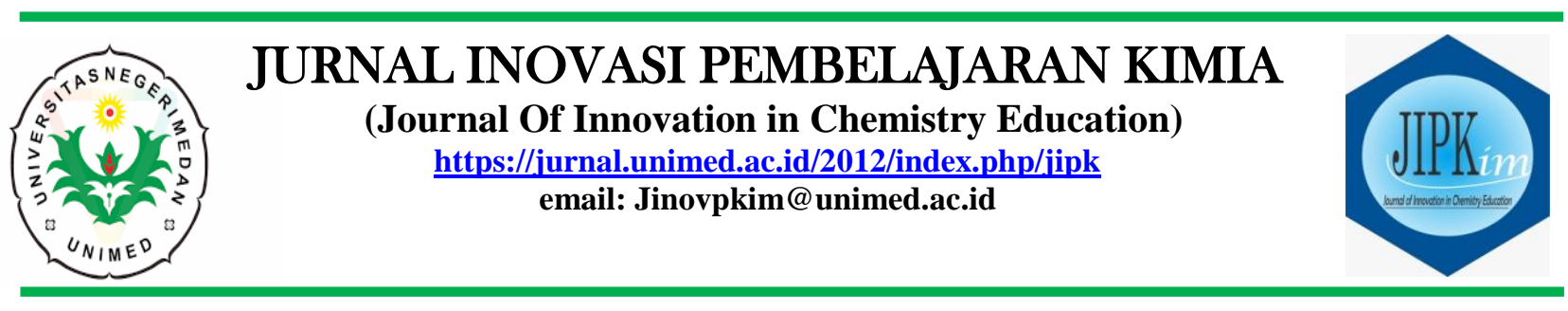

$\begin{array}{ll}\text { Masuk } & : \text { 28 Januari } 2021 \\ \text { Revisi } & : 28 \text { Maret } 2021 \\ \text { Diterima } & : 7 \text { April } 2021 \\ \text { Diterbitkan } & : 18 \text { April } \\ \text { Halaman } & : 1-10\end{array}$

\title{
Analisis Keterampilan Proses Sains Peserta Didik Pada Materi Ikatan Kimia Kelas X SMAN 6 Madiun
}

\author{
Agustyna Widyaningrum ${ }^{1 *}$, Rudiana Agustini ${ }^{2}$ \\ ${ }^{1,2}$ Program Studi Pendidikan Kimia, Universitas Negeri Surabaya, Surabaya \\ *Alamat Korespondensi: agustyna.17030194004@mhs.unesa.ac.id
}

\begin{abstract}
This study aims to describe the science process skills of students on each indicator and to find out the average percentage of students who have a science process skill level category (high, medium, and low) chemical bonding material with the POGIL learning model. This research uses pre-experimental research with the one group pretest posttest research desaign. The data collection techniques used were observation and assessment tests. The data analysis technique used paired T-Test (SPSS version 16) and $N$-gain Score. The results showed that the data were normally distributed, namely the Sig.> 0.05. Paired Sample T-Test obtained Sig. (2-tailed) of 0.00, which means that the test is <0.05. So it can be concluded that the POGIL learning model has a significant effect on the science process skills of students. The science process skills of the five indicators, the classification indicator has the highest average posttest score percentage of $96.21 \%$ and the observing indicator has the lowest average posttest score percentage of $71.21 \%$. Science process skills have increased from the average results of the pretest and posttest values, namely from $65.76 \%$ to $88.41 \%$. The improvement of science process skills is in the moderate category with the $N$-gain Score index of 0.67.
\end{abstract}

Keywords: Science Process Skills, POGIL, Chemical Bonds

\section{PENDAHULUAN}

Pendidikan adalah suatu proses sadar dan terencana sebagai upaya menciptakan proses pembelajaran yang bermakna. Melalui proses pendidikan, peserta didik dilatih kemampuan dan potensi untuk berkembang secara optimal diwujudkan melalui belajar bermakna di sekolah (Gabby et al., 2017). Mengembangkan kemampuan diri sebagai inti dari paradigma konstruktivis yang merupakan tujuan pembelajaran yang berarti. Peserta didik mampu meningkatkan peringkat keahlian yang dimiliknya, seperti berpikir kritis, komunikasi, kolaboratif, serta kreatif dengan pembelajaran yang bermakna supaya siap untuk bersaing di abad 21 (Laksana, 2017). Contoh pembelajaran yang bermakna salah satunya yaitu pembelajaran sains. Pembelajaran sains adalah pembelajaran yang tidak sekedar memfokuskan untuk penguasaan-penguasaan hasil, tetapi penguasaan keterampilan proses serta perilaku ilmiah (Juhji, 2016). Pembelajaran yang terpenting dalam penanaman konsep sains yaitu mengajarkan peserta didik keterampilan proses sains. 
Keterampilan proses sains ialah keahlian intelektual dalam mengumpulkan pemahaman, merefleksikan masalah serta menyebutkan hasilnya (Aydin, 2013). Peserta didik yang tidak bisa menerapkan atau menggunakan keterampilan proses sains akan mengalami kesulitan, disebabkan keterampilan ini tidak hanya digunakan di sekolah namun digunakan juga di kehidupan sehari-hari untuk memecahkan masalah.

Salah satu ilmu sains yang perlu dipelajari dengan keterampilan proses sains adalah kimia, karena memiliki keterkaitan konsep yang erat. Konsep-konsep yang lain dapat dibangun dengan pemahaman konseptual yang mendasar (Ariani et al., 2015). Materi kimia yang diajarkan salah satunya adalah ikatan kimia sesuai dengan kurikulum 2013. Kimia tidak sekedar kecakapan keterampilan tentang konsep, fakta, prinsip serta proses penemuannya (Rahmadhani \& Novita, 2018). Model pembelajaran untuk melatihkan keterampilan proses sains salah satunya POGIL. Model pembelajaran POGIL merupakan penemuan konsep, dari penemuan konsep itu peserta didik telah melakukan dan membiasakan untuk melakukan ketrampilan proses sains. Sintak pembelajaran POGIL yakni orientasi, eksplorasi, pembetukan konsep aplikasi dan penutup. Peserta didik dapat menemukan pengetahuan baru dalam proses belajar secara kelompok ataupun individu dengan model pembelajaran POGIL (Adzani et al., 2019). Model pembelajaran POGIL memiliki kelebihan yaitu mendorong supaya mendapatkan pengetahuan dengan sendirinya dan dapat digunakan untuk semua jejang pendidikan. Model pembelajaran POGIL memiliki kelebihan yaitu mendorong supaya mendapatkan pengetahuan dengan sendirinya dan dapat digunakan untuk semua jejang pendidikan. Peserta didik sangat terbantu untuk mengembangkan keterampilan proses sains seperti keterampilan menanya, mengkomunikasi dengan menggunakan model POGIL (Malik et al., 2017).

Hasil penelitian (Fitriana, Yenni Kurniawati \& Lisa Utami 2019) di SMAN 16 Pekanbaru, peserta didik masih pasif untuk mengikuti pembelajaran yang berlangsung. Pembelajaran masih didominasi oleh peran guru serta cenderung hanya menguraikan sebagian keterampilan saja, seperti keterampilan mengajukan pertanyaan dan keterampilan berkomunikasi. Sedangkan keterampilan proses yang lainnya tidak dilatih dengan baik dan cenderung diabaikan (Fitriana et al., 2019).

Hasil penelitian dan wawancara (Fatria Dewi, Afrida, \& Bayu Efrianto 2018) dengan peserta didik serta guru kimia di SMAN 1 Jambi diketahui materi ikatan kimia sulit dipahami oleh peserta didik. Kesulitan yang dihadapi yaitu membentuk ikatan ion dan ikatan kovalen dengan struktur lewis (Dewi et al., 2018).

Hasil diatas diperkuat dengan hasil pra penelitian yang dilakukan di SMA Negeri 6 Madiun Tahun ajaran 2020/2021. Hasil angket pra penelitian yang dilakukan di SMA Negeri 6 Madiun diperoleh sebanyak 94,1\% peserta didik merasa pelajaran kimia itu sulit. Hal ini karena ada materi dan rumus yang sulit untuk dipahami. Hasil angket sebesar $55,9 \%$ perserta didik menganggap bahwa materi kimia yang sulit adalah materi ikatan kimia. Hal ini karena perserta didik menganggap bahwa materi bersifat abstrak sehingga sulit untuk dipahami. Hasil angket $67,6 \%$ peserta didik memilih jarang diajarkan ketrampilan proses sains oleh guru. Berdasarkan permasalahan yang didapatkan diatas, perlu dikaji tentang bagaimana tingkat keterampilan proses sains yang telah dimiliki peserta didik. Keterampilan peserta didik dalam menemukan konsep kimia harus sejalan dengan keterampilan proses sains agar tujuan pembelajaran dapat tercapai sesuai yang diharapkan. Penelitian ini berusaha mendeskripsikan keterampilan proses sains yang dimiliki peserta didik setiap indikator dan mengetahui rata-rata presentase peserta didik yang memiliki tingkat keterampilan proses sains kategori tinggi, sedang, dan rendah. Keterampilan proses sains mempunyai beberapa indikator yaitu mengamati, menginferesi, memprediksi, mengklasifikasi, dan 


\section{Agustyna Widyaningrum dan Rudiana Agustini \\ Jurnal Inovasi Pembelajaran Kimia (Journal Of Innovation in Chemistry Education) Volume 3, Nomor 1, April 2021 \\ Analisis Keterampilan Proses Sains Peserta Didik Pada Materi lkatan Kimia Kelas X SMAN 6 Madiun}

mengkomunikasi. Mengamati merupakan kegiatan pengamatan fenomena alam dan objek dengan pancaindra. Keterampilan proses sains yang paling dasar adalah mengamati, karena dengan melakukan pengamatan akan memperoleh ilmu pengetahuan yang digunakan dalam menguraikan keterampilan proses sains lainnya. Menginferensi merupakan keterampilan menjelaskan objek atau fenomena alam. Memprediksi yaitu keterampilan untuk memperkirakan yang akan terjadi waktu mendatang dengan menghubungkan antara fakta, konsep, prinsip dalam ilmu pengetahuan. Mengklasifikasi adalah keterampilan untuk memilih berbagai objek berdasarkan karakteristik, sehingga dapat di kelompokan atau di klasifikasi dari objek yang dimaksud. Mengkomunikasi merupakan keterampilan berkomunikasi dengan orang lain untuk menyampaikan hasil kerjanya.

\section{KAJIAN LITERATUR}

Menurut (Iqbal \& Husni, 2020) proses mencari dan menemukan pengetahuan aktivitas sains, penyelidikan ilmiah, pemecahan masalah, maupun pengambilan keputusan terkait isu-isu sains merupakan keterampilan proses sains yang dimiliki ilmuan (Limatahu \& Mubarok, 2020).

Menurut (Nirwana \& Haryani, 2016) keterampilan proses sains bisa dikembangkan dengan pengalaman pembelajaran langsung, karena dapat menghayati pembelajaran yang dilakukan secara pengalaman langsung. Melatihkan keterampilan ini perlu model yang sesuai yaitu model POGIL (Hafshoh Dwi Nirwana, Sri Haryani, 2016).

Menurut (Ramdani \& Sedijani, 2017) model pembelajaran POGIL memengaruhi pemahaman tentang konsep sains, keterampilan proses sains, dan keterampilan berpikir kritis.

\section{METODE}

Jenis penelitian ini adalah Pre Eksperimental dengan desain penelitian one grup pretest posttest. Peserta didik dalam penelitian ini diberikan pretest sebelum perlakuan. Kemudian diberikan posttest untuk mengetahui kondisi akhir peserta didik setelah diberikan perlakuan. Desain penelitian dapat digambarkan sebagai berikut.

\section{$\mathrm{O}_{1} \mathrm{X} \mathrm{O}_{2}$}

Keterangan:

$\mathrm{O}_{1}$ :Hasil tes keterampilan proses sains sebelum penerapan model pembelajaran POGIL pada materi ikatan kimia

$\mathrm{X}$ :Penerapan model pembelajaran POGIL pada materi ikatan kimia

$\mathrm{O}_{2}$ :Hasil tes keterampilan proses sains setelah penerapan model pembelajaran POGIL pada materi ikatan kimia

Peserta didik kelas X MIPA 4 SMA Negeri 6 Madiun menjadi objek penelitian. Penelitian ini dilaksanakan pada semester ganjil tahun ajaran 2020/2021 menggunakan satu kelas saja dan jumlah peserta didik 33 orang tanpa kelas pembanding.

Teknik mengumpulkan data menggunakan observasi (lembar keterlaksanaan model pembelajaran) dan tes penilaian (lembar soal pretets dan posttest keterampilan proses sains). Memperoleh data keterlakasaan model pembelajaran POGIL menggunakan observasi.

Observasi dilakukan oleh 3 pengamat 2 dari mahasiswa pendidikan kimia dan 1 dari guru kimia SMA Negeri 6 Madiun. Tes penilaian dilaksanakan dua kali yaitu sebelum (pretest) dan sesudah (posttest) diterapkan model pembelajaran POGIL yang digunakan untuk mengukur keterampilan proses sains.

Soal berbentuk uraian yang terdiri dari tujuh soal yang mewakili indikator keterampilan proses sains yaitu mengamati, menginferensi, memprediksi, mengklasifikasi, dan mengkomunikasi. Rubrik masing-masing indikator terdapat pada tabel 1 sebagai berikut. 
Analisis Keterampilan Proses Sains Peserta Didik Pada Materi Ikatan Kimia Kelas X SMAN 6 Madiun

Tabel 1. Rubrik Penilaian pretest posttest keterampilan proses sains

\begin{tabular}{c}
\hline Keterampila \\
Proses Sain \\
\hline Mengamati \\
Fenomena
\end{tabular}

Menginferensi

Memprediksi

$\begin{array}{cl}\text { 1.Mengumpulkan } & \text { 0= tidak } \\ \text { satu informasi } & \text { menjawab } \\ \text { mengenai } & \text { 1= menjawab } \\ \text { fenomena } & \text { tetapi tidak } \\ \text { tersebut } & \text { memenuhi } \\ \text { 2. Mengumpulkan } & \text { semua } \\ \text { dua informasi } & \text { indikator } \\ \text { mengenai } & \text { 2= menjawab } \\ \text { fenomena } & \text { dengan } \\ \text { tersebut } & \text { mencakup } \\ \text { 3. Mengumpulkan } & \text { satu indikator } \\ \text { tiga informasi } & \text { 3= menjawab } \\ \text { mengenai } & \text { dengan } \\ \text { fenomena } & \text { mencakup dua } \\ \text { tersebut } & \text { indikator } \\ & \text { 4= menjawab } \\ & \text { dengan } \\ & \text { mencakup } \\ & \text { tiga indikator }\end{array}$

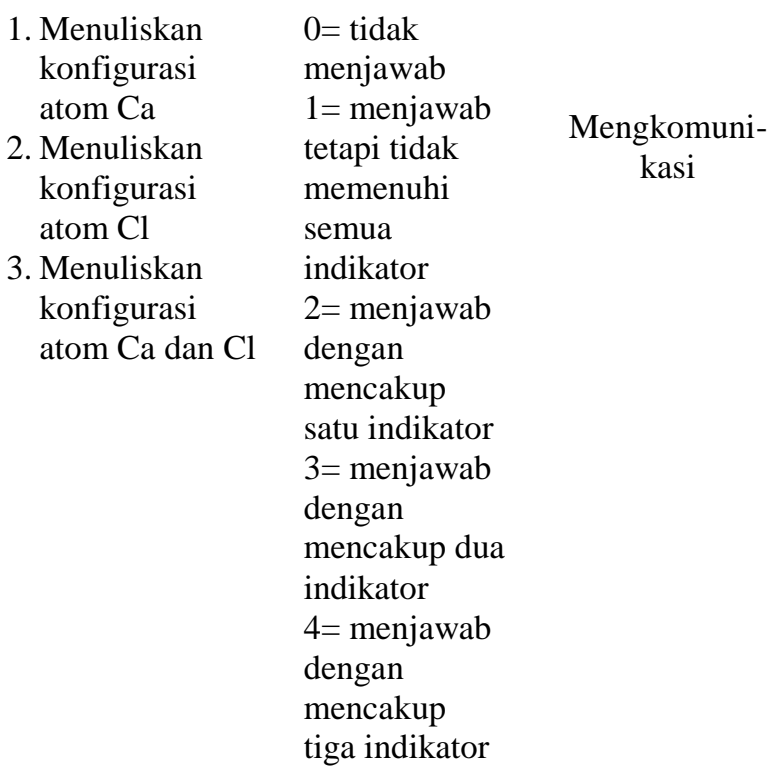

\begin{tabular}{lll}
\hline $\begin{array}{c}\text { Keterampilan } \\
\text { Proses Sains }\end{array}$ & \multicolumn{1}{c}{ Indikator } & \multicolumn{1}{c}{ Penilaian } \\
& atom atom Cl & indikator \\
& menangkap 1 & 4= menjawab \\
elektron & dengan \\
& & mencakup \\
& & tiga indikator \\
\end{tabular}

Mengklasifikasi

1. Mengelompok- $\quad 0=$ tidak kan ikatan ion menjawab saja 1= menjawab

2. Mengelompok- tetapi tidak kan ikatan kovalen saja 3. Mengelompokkan ikatan ion dan ikatan kovalen memenuhi semua indikator $2=$ menjawab dengan mencakup satu indikator $3=$ menjawab dengan mencakup dua indikator 4= menjawab dengan mencakup tiga indikator

1. Menyampaikan $\quad 0=$ tidak ikatan ion dan menjawab contohnya saja $1=$ menjawab

2. Menyampaikan tetapi tidak ikatan kovalen memenuhi dan contohnya semua saja indikator

3. Menyampaikan $2=$ menjawab ikatan ion, dengan ikatan kovalen mencakup dan ikatan satu indikator kovalen $3=$ menjawab koordinasi dengan mencakup dua indikator 4= menjawab dengan mencakup tiga indikator

$\begin{array}{ll}\text { 1. Membuat } & 0=\text { tidak } \\ \text { inferensi yaitu } & \text { menjawab } \\ \text { atom Ca } & \text { 1= menjawab } \\ \text { melepas 2 } & \text { tetapi tidak } \\ \text { elektron } & \text { memenuhi } \\ \text { 2. Membuat } & \text { semua } \\ \text { inferensi yaitu } & \text { indikator } \\ \text { atom Cl } & \text { 2= menjawab } \\ \text { menangkap 1 } & \text { dengan } \\ \text { elektron } & \text { mencakup } \\ \text { 3. Membuat } & \text { satu indikator } \\ \text { inferensi atom } & \text { 3= menjawab } \\ \text { Ca melepas 2 } & \text { dengan } \\ \text { elektron dan } & \text { mencakup dua }\end{array}$

Data yang sudah didapatkan tesebut dianalisis dengan mendeskripsikan setiap indikator keterampilan proses sains dan mengetahui rata-rata presentase peserta didik yang memiliki keterampilan proses sains kategori tinggi, sedang, dan rendah. Nilai hasil pretest dan posttest dianalisis menggunkan Uji T-Test berpasangan (SPSS versi 16) untuk menentukan signifikansi perbedaan hasil pretest dan posttest. Syarat 
Uji T-Test berpasangan terlebih dilakukan Uji Normalitas. Jika data dikatakan berdistribusi Normal, maka dilakukan Uji TTest berpasangan. Uji $\mathrm{N}$-gain score dilakukan untuk menentukan kategori peningkatan hasil pretest dan posttest.

Analisis keteraksanaan pembelajaran POGIL dilakukan dengan cara menghitung presentase sintak-sintak yang terlaksana selama pembelajaran berlangsun dan dihitung dengan rumus sebagai berikut:

$$
\mathrm{P}(\%)=\frac{\text { jumlah hasil perhitungan }}{\text { skor kriterium }} \times 100 \%
$$

Keterangan:

$\mathrm{P}=$ presentase

Skor Kriterium $=$ skor tertinggi $\times$ aspek

Kemudian hasil presentase keterlaksanaan sintak-sintak selama pembelajaran dihasilkan serta dikonversikan sesuai kategori sebagai berikut:

Tabel 2. Kategori Keterlaksanaan

\begin{tabular}{cc}
\hline Persentase (\%) & Kategori \\
\hline $0 \%-20 \%$ & Sangat Buruk \\
$21 \%-40 \%$ & Buruk \\
$41 \%-60 \%$ & Sedang \\
$61 \%-80 \%$ & Baik \\
$81 \%-100 \%$ & Sangat Baik \\
\hline
\end{tabular}

(Riduwan, 2011)

Peningkatan ketrampilan proses sains siswa setelah diterapkannya pembelajaran inkuiri POGIL ditetapkan sesuai nilai indeks gain. Berikut rumus N-gain:

$$
\mathrm{G}=\frac{\text { skor posttest-skor pretest }}{\text { skor maksimal-skor pretest }}
$$

Kriteria tingkat $\mathrm{N}$-gain ditunjukan pada tabel berikut:

Tabel 3. Kriteria nilai N-gain

\begin{tabular}{cc}
\hline Nilai & Kriteria \\
\hline $0,0<(<\mathrm{g}>) \leq 0,3$ & Rendah \\
$0,3<(<\mathrm{g}>) \leq 0,7$ & Sedang \\
$0,7<(<\mathrm{g}>) \leq 1,0$ & Tinggi \\
\hline
\end{tabular}

(Riduwan, 2011)

\section{HASIL DAN PEMBAHASAN \\ Keterlaksanaan Pembelajaran POGIL}

Pada penelitian ini semua perangkat pembelajaran sudah di validasi oleh 2 Dosen validator (Dosen Pendidikan Kimia Universitas Negeri Surabaya). Keterlaksanaan model pembelajaran POGIL di observasi oleh 3 orang pengamat, yaitu 2 orang dari mahasiswa pendidikan kimia Universitas Negeri Surabaya dan 1 orang dari Guru Kimia SMA Negeri 6 Madiun. Pembelajaran dan pengamatan dilakukan secara daring menggunakan platform googlemeet, karena masih ada pandemi COVID 19. Kemudian data di olah sesuai dengan rubrik penilaian lembar keterlaksanaan model pembelajaran POGIL. Data keterlaksanaan model pembelajaran POGIL mengambarkan kemampuan pendidik untuk menerapkan fase-fase pembelajaran POGIL dalam pembelajaran kimia di kelas. Data hasil pengamatan pada fase-fase POGIL disajikan pada Tabel 4.

Tabel 4. Keterlaksanaan Pembelajaran POGIL

\begin{tabular}{lcr}
\hline Aspek yang dinilai & \multicolumn{2}{c}{ Keterlaksanaan } \\
\cline { 2 - 3 } & $\begin{array}{c}\text { Pertemuan } \\
\text { 1\% }\end{array}$ & $\begin{array}{c}\text { Pertemuan } \\
2 \%\end{array}$ \\
\hline Pendahuluan & 96,43 & 98,81 \\
Fase 1: Orientasi & 97,92 & 95,83 \\
Fase 2: Eksplorasi & 97,57 & 96,53 \\
Fase 3: Pembentukan & 91,75 & 100 \\
Konsep & & \\
Fase 4: Aplikasi & 100 & 95,75 \\
Fase 5: Penutup & 98,61 & 98,50 \\
Penutup & 95,75 & 100 \\
Rata-Rata & 96,86 & 97,92 \\
\hline
\end{tabular}

Berdasarkan data pada Tabel 4 di ketahui keterlaksanaan model pembelajaran POGIL yang dilaksanakan selama penelitian dalam dua pertemuan dan dilakukan secara daring menggunakan platform googlemeet didapatkan $96,86 \%$ pertemuan pertama dan 97,92\% pertemuan kedua. Perolehan ini dapat dipastikan bahwa keterlaksanaan model pembelajaran POGIL selama penelitian masuk kriteria baik sekali.

\section{Keterampilan Proses Sains}

Data hasil penelitian ini di peroleh dari hasil penilaian tes yaitu penilaian sebelum penerapan model pembelajaran POGIL 


\section{Agustyna Widyaningrum dan Rudiana Agustini \\ Jurnal Inovasi Pembelajaran Kimia (Journal Of Innovation in Chemistry Education) Volume 3, Nomor 1, April 2021 Analisis Keterampilan Proses Sains Peserta Didik Pada Materi lkatan Kimia Kelas X SMAN 6 Madiun}

(pretest) dan sesudah penerapan model pembelajaran POGIL (posttest) keterampilan proses sains yang berupa soal uraian terdiri dari tujuh soal yang mewakili setiap indikator keterampilan proses sains. Hasil analisis keterampilan proses sains yang dimiliki peserta didik pada nilai pretest tergolong kriteria baik dan mengalami peningkatan nilai posttest menjadi kriteria sangat baik. Presentase hasil pretest dan posttest keterampilan proses sains peserta didik disajikan pada Tabel 5.

Tabel 5. Presentase Nilai Keterampilan Proses Sains Setiap Indikator

\begin{tabular}{lclcl}
\hline Indikator & $\begin{array}{c}\text { \% } \\
\text { Pre- } \\
\text { test }\end{array}$ & Kriteria & $\begin{array}{c}\text { \% } \\
\text { Post- } \\
\text { test }\end{array}$ & Kriteria \\
\hline $\begin{array}{l}\text { Mengamati } \\
\text { Menginfe- } \\
\text { rensi }\end{array}$ & 75,70 & Cukup & 71,21 & Baik \\
$\begin{array}{l}\text { Mempre- } \\
\text { diksi }\end{array}$ & 53,41 & Baik & 95,45 & $\begin{array}{l}\text { Sangat } \\
\text { Baik }\end{array}$ \\
$\begin{array}{l}\text { Mengkla- } \\
\text { sifikasi }\end{array}$ & 91,67 & Sangat & 86,21 & $\begin{array}{l}\text { Sangat } \\
\text { Baik }\end{array}$ \\
$\begin{array}{l}\text { Meng- } \\
\text { komunikasi } \\
\text { Rata-Rata }\end{array}$ & 63,26 & Baik & 92,05 & $\begin{array}{l}\text { Sangat } \\
\text { Baik }\end{array}$ \\
\hline
\end{tabular}

Berdasarkan Tabel 5 pada presentase pretest terdapat 2 indikator keterampilan proses sains yang termasuk kriteria cukup yaitu mengamati dan memprediksi. Kemudian terdapat 2 indikator yang termasuk kriteria baik yaitu menginferensi dan mengkomunikasi. Dan terdapat 1 indikator yang termasuk kriteria sangat baik yaitu mengklasifikasi. Pada presentase posttest terdapat 1 indikator keterampilan proses sains yang termasuk kriteria baik yaitu mengamati. Kemudian terdapat 4 indikator yang termasuk kriteria sangat baik yaitu menginferensi, memprediksi, mengklasifikasi, dan mengkomunikasi. Keterampilan proses sains dilihat dari presentase keseluruhan indikator pada pretest termasuk kriteria baik dengan presentase $65,76 \%$, sedangkan pada posttest termasuk kriteria sangat baik dengan presentase $88,41 \%$, yang membuktikan bahwa keterampilan proses sains peserta didik kelas X MIPA 4 harus dipertahankan dan sering dilatihkan dalam kegiatan pembelajaran supaya semua peserta didik memiliki kemampuan yang diperlukan khususnya keterampilan proses sains. Hal ini sesuai dengan teori psikologi belajar yaitu untuk meningkatkan kemampuan di bidang tertentu harus berlatih dan mengembangkan keterampilan tersebut secara terus-menerus supaya menjadi terbiasa (Fitriana et al., 2019).

Peserta didik dengan presentase posttest tertinggi keterampilan proses sains yaitu pada indikator mengklasifikasi, sementara presentase posttest terendah yaitu pada indikator mengamati yang ditunjukkan gambar 1.

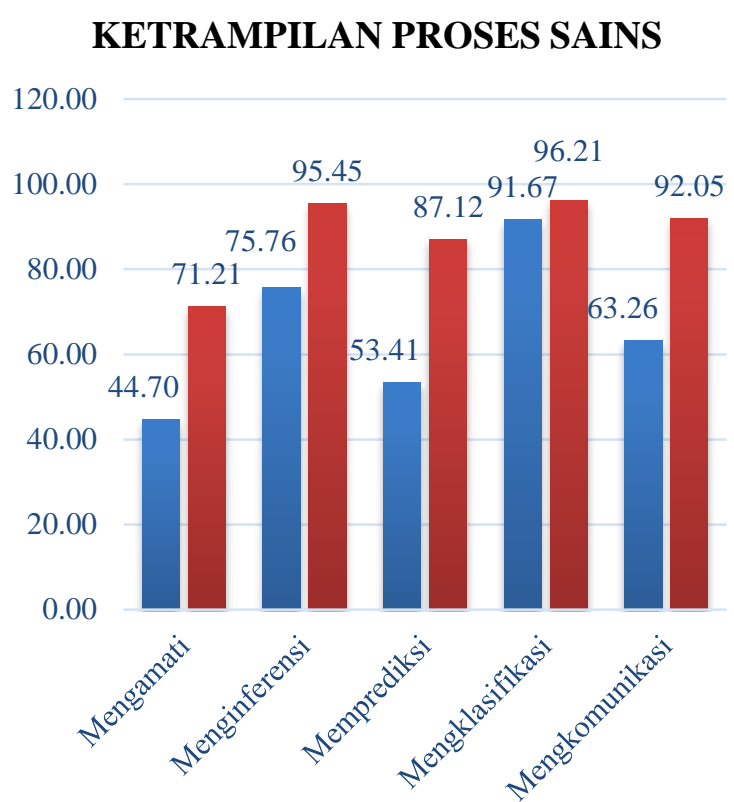

Gambar 1. Presentase Pretest dan Posttest Tiap Indikator Keterampilan Proses Sains

Gambar 1 menunjukkan indikator mengamati memperoleh presentase pretest sebesar $44,70 \%$ kemudian pada posttest mengalami peningkatan menjadi $71,21 \%$, karena peserta didik menjawab soal posttest dengan benar, namun peserta didik kurang lengkap untuk menuliskan hasil pengamatan dan kurang memberikan penjelasan pada gambar yang terdapat pada soal posttest. Indikator mengamati pada keterampilan proses sains memberikan pembelajaran yang lebih bermakna. Peserta didik dapat meningkatkan kualitas sumber daya seperti berpikir kritis, kolaboratif, 
komunikasi dan kreatif dengan pembelajaran yang bermakna supaya siap untuk bersaing di abad 21(Laksana, 2017). Keterampilan mengamati dapat menjadi titik fokus dalam mengembangkan keterampilan proses sains yang lainnya (Yuliati, 2016).

Keterampilan proses sains pada indikator menginferensi pada gambar 1 menunjukkan presentase pretest sebesar $75,76 \%$ kemudian pada posttest mengalami peningkatan menjadi 95,45\%. Hal ini terjadi karena peserta didik menjawab soal posttest dengan benar tetapi sebagian masih ada yang kurang lengkap untuk menjelaskan.

Keterampilan proses sains pada indikator memprediksi pada gambar 1 menunjukkan presentase pretest sebesar 53,41\% kemudian pada posttest mengalami peningkatan menjadi $87,12 \%$. Hal ini terjadi karena sebagian besar peserta didik sudah menjawab soal posttest dengan benar tetapi kurang lengkap. Keterampilan memprediksi merupakan keterampilan yang bersumber pada perkiraan pola tertentu dalam menghubungankan antara fakta, konsep dan prinsip ilmu pengetahuan.

Keterampilan proses sains pada indikator mengklasifikasi pada gambar 1 menunjukkan presentase pretest sebesar 91,67\% kemudian pada posttest mengalami peningkatan menjadi 96,21\%. Hal ini terjadi karena peserta didik sudah menjawab dengan benar dan lengkap serta sangat memperhatikan pertanyaan posttest yang disajikan.

Keterampilan proses sains pada indikator mengkomunikasi pada gambar 1 menunjukkan presentase pretest sebesar $63,26 \%$ kemudian pada posttest mengalami peningkatan menjadi $92,05 \%$. Hal ini terjadi karena peserta didik mampu membuat kesimpulan dari pembelajaran yang sudah diajarkan dengan baik pada soal posttest.

Penjelasan diatas sesuai dengan teori penemuan Jerome Bruner yang berpendapat bahwa manusia belajar untuk menemukan dan mencari secara aktif dengan sendirinya memberikan hasil yang baik, serta usaha sendiri dalam menemukan solusi yang menghasilkan pengetahuan bermakna.

Kategori peningkatan nilai pretest dan posttest keterampilan proses sains bisa dilihat daru Uji N-gain Score. Berikut ini disajikan hasil Uji N-gain Score 33 peserta didik pada Tabel 6.

Tabel 6. N-gain Score

\begin{tabular}{|c|c|c|c|c|}
\hline Siswa & $\begin{array}{c}\text { Pre- } \\
\text { test }\end{array}$ & $\begin{array}{c}\text { Post- } \\
\text { test }\end{array}$ & $\begin{array}{c}\mathrm{N} \text {-gain } \\
\text { Score }\end{array}$ & Ket. \\
\hline 1 & 57 & 89 & 0,74 & Tinggi \\
\hline 2 & 57 & 86 & 0,67 & Sedang \\
\hline 3 & 61 & 82 & 0,54 & Sedang \\
\hline 4 & 57 & 92 & 0,81 & Tinggi \\
\hline 5 & 61 & 89 & 0,72 & Tinggi \\
\hline 6 & 61 & 82 & 0,54 & Sedang \\
\hline 7 & 82 & 96 & 0,78 & Tinggi \\
\hline 8 & 82 & 92 & 0,56 & Sedang \\
\hline 9 & 60 & 78 & 0,45 & Sedang \\
\hline 10 & 46 & 82 & 0,67 & Sedang \\
\hline 11 & 78 & 92 & 0,64 & Sedang \\
\hline 12 & 75 & 92 & 0,68 & Sedang \\
\hline 13 & 82 & 92 & 0,56 & Sedang \\
\hline 14 & 57 & 89 & 0,74 & Tinggi \\
\hline 15 & 57 & 92 & 0,81 & Tinggi \\
\hline 16 & 64 & 89 & 0,69 & Sedang \\
\hline 17 & 71 & 86 & 0,52 & Sedang \\
\hline 18 & 60 & 96 & 0,90 & Tinggi \\
\hline 19 & 71 & 92 & 0,72 & Tinggi \\
\hline 20 & 64 & 86 & 0,61 & Sedang \\
\hline 21 & 46 & 86 & 0,74 & Tinggi \\
\hline 22 & 35 & 89 & 0,83 & Tinggi \\
\hline 23 & 82 & 96 & 0,78 & Tinggi \\
\hline 24 & 42 & 86 & 0,76 & Tinggi \\
\hline 25 & 67 & 86 & 0,58 & Sedang \\
\hline 26 & 57 & 89 & 0,74 & Tinggi \\
\hline 27 & 75 & 86 & 0,44 & Sedang \\
\hline 28 & 71 & 89 & 0,62 & Sedang \\
\hline 29 & 50 & 86 & 0,72 & Tinggi \\
\hline 30 & 67 & 89 & 0,67 & Sedang \\
\hline 31 & 53 & 82 & 0,62 & Sedang \\
\hline
\end{tabular}




\begin{tabular}{ccccc}
\hline Siswa & $\begin{array}{c}\text { Pre- } \\
\text { test }\end{array}$ & $\begin{array}{c}\text { Post- } \\
\text { test }\end{array}$ & $\begin{array}{c}\text { N-gain } \\
\text { Score }\end{array}$ & Ket. \\
\hline 32 & 71 & 92 & 0,72 & Tinggi \\
33 & 71 & 89 & 0,62 & Sedang \\
Rata- & & & 0,67 & \\
Rata & & & & \\
Ket. & & & Sedang & \\
\hline
\end{tabular}

Pada Tabel 6 terlihat indeks N-gain ratarata 0,67 termasuk kategori sedang, hal ini disebabkan peserta didik belum terbiasa menerapkan keterampilan proses sains. Peserta didik akan menguasai keterampilan proses sains jika dilatihkan secara berulangulang dan berkelanjutan sehingga terbiasa. Hal ini sesuai dengan teori Slavin bahwa pengulangan dan latihan sangat penting untuk mempertahankan ingatan jangka panjang.

Keterampilan proses sains peserta didik meningkat setelah menerapkan model POGIL pada materi ikatan kimia dengan hasil Uji T-Test berpasangan (SPSS versi 16) terhadap hasil pretest dan posttest keterampilan proses sains. Syarat melakukan Uji T-Test berpasangan terlebih dahulu melakukan Uji Normalitas untuk menentukan bahwa data berdistribusi normal atau tidak.

Tabel 7. Uji Normalitas

\begin{tabular}{|c|c|c|c|c|c|c|}
\hline & \multicolumn{3}{|c|}{$\begin{array}{c}\text { Kolmogorov- } \\
\text { Smirnov }^{\mathrm{a}}\end{array}$} & \multicolumn{3}{|c|}{ Shapiro-Wilk } \\
\hline & Statistic & Df & Sig. & Statistic & Df & Sig. \\
\hline $\begin{array}{l}\text { Pre } \\
\text { Test }\end{array}$ & .117 & 33 & $.200^{*}$ & .964 & 33 & .337 \\
\hline $\begin{array}{l}\text { Post } \\
\text { Test }\end{array}$ & .148 & 33 & .064 & .936 & 33 & .051 \\
\hline
\end{tabular}

a. Lilliefors Significance

Correction

*. This is a lower bound of the true significance.

Berdasarkan Tabel 7 data dianalisis menggunakan Shapiro-Wilk, karena data kurang dari 50. Dari Tabel 5 Uji Normalitas diketahui bahwa data sudah normal, karena nilai signifikan dari pretest dan posttest lebih dari 0,05. Data yang sudah terdistribusi normal dilakukan Uji T-Test berpasangan pada hasil pretest dan posttest keterampilan proses sains.

Berdasarkan Tabel 8 dibawah ini, menghasilkan nilai signifikan yaitu $0,000<$ 0,05 mengindikasikan bahwa $\mathrm{H} 0$ ditolak dan Ha diterima, sehingga ada perbedaan ratarata nilai pretest dan nilai posttest keterampilan proses sains. Keterampilan proses sains meningkat karena adanya pengaruh model POGIL.

Tabel 8. Uji T-Test Berpasangan

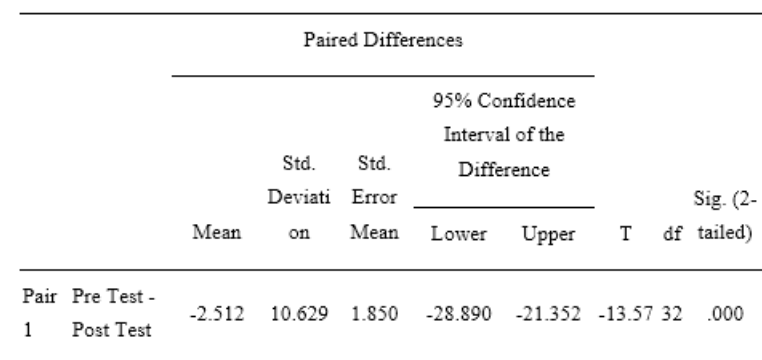

Peserta didik memiliki keterampilan proses sains yang dapat dikelompokkan sesuai dengan kategori rendah, sedang dan tinggi. Kategori ini dapat dilihat dari hasil Ngain Score yang didapat dari nilai pretest dan posttest keterampilan proses sains setiap peserta didik.

Tabel 9. Hasil Uji N-gain Score Setiap Peserta Didik

\begin{tabular}{ccc}
\hline N-gain & Kategori & $\begin{array}{c}\text { Jumlah } \\
\text { Peserta Didik }\end{array}$ \\
\hline $0,0<(<\mathrm{g}>) \leq 0,3$ & Rendah & 0 \\
$0,3<(<\mathrm{g}>) \leq 0,7$ & Sedang & 18 \\
$0,7<(<\mathrm{g}>) \leq 1,0$ & Tinggi & 15 \\
Rata-rata N-gain & Sedang & \\
$\mathbf{0 , 6 7}$ & & \\
\hline
\end{tabular}

Berdasarkan Tabel 9 terlihat bahwa peserta didik yang memiliki keterampilan proses sains kategori tinggi berjumlah 15, sedang berjumlah 18 , dan rendah berjumlah 0 , karena peserta didik kelompok tinggi mampu menjawab posttest dengan baik. Peserta didik kelompok sedang sudah mampu menjawab posttest dengan baik, namun belum mampu menginterpretasikan keterampilan proses sainsnya (Fitriana et al., 2019). 


\section{DISKUSI}

Jadi, berdasarkan hasil analisis peserta didik di SMA Negeri 6 Madiun mengalami kenaikan hasil pretest dan posttest dari kriteria baik menjadi sangat baik ditunjukkan dengan hasil uji T-Test berpasangan menghasilkan nilai signifikan 0,000 yang membuktikan bahwa $\mathrm{H} 0$ ditolak dan $\mathrm{Ha}$ diterima sehingga, ada perbedaan rata-rata hasil pretest dan hasil posttest keterampilan proses sains.

Indikator mengklasifikasi pada keterampilan proses sains menghasilkan nilai pretest tertinggi yakni $91,67 \%$, sedangkan posttest yang tertinggi juga pada indikator mengklasifikasi yaitu 96,21\%. Indikator mengamati pada keterampilan proses sains menghasilkan nilai pretest yang terendah yaitu 44,70\%, sedangkan posttest yang terendah juga pada indikator mengamati yaitu $71,21 \%$. Hal ini karena, peserta didik kurang lengkap untuk menuliskan hasil pengamatan dan kurang memberikan penjelasan yang sesuai terhadap soal yang disajikan. Jadi, keterampilan proses sains peserta didik harus diperhatikan serta dilatihkan terus-menerus dalam kegiatan pembelajaran, supaya terbiasa dan mampu untuk menyelesaikan permasalahanpermasalahan khususnya permasalahan dalam bidang kimia dengan menggunakan keterampilan proses sains (Fitriana et al., 2019). Hal ini sesuai dengan teori Slavin bahwa untuk mempertahankan kemampuan atau keterampilan ingatan jangka panjang dapat melatihkan secara berulang-ulang materi yang penting. Model pembelajaran POGIL pada materi Ikatan Kimia bisa memudahkan peserta didik supaya bisa menerapkan keterampilan proses sains di sekolah maupun diluar sekolah, karena model POGIL mendukung peserta didik untuk meningkatkan keterampilan proses sains (Malik et al., 2017).

\section{KESIMPULAN}

Keterampilan proses sains yang dimiliki oleh peserta didik setiap indikator pada posttest yaitu sebesar $71,21 \%$ mengamati,
$95,45 \%$

menginferensi,

$87,12 \%$

memprediksi, 96,21\% mengklasifikasi dan 92,05\% mengkomunikasi. Peserta didik memiliki presentase rata-rata keterampilan proses sains yaitu $67 \%$ kategori sedang.

\section{DAFTAR PUSTAKA}

Adzani Fitriana, A., Rsilawati, I., \& Diawati, C. (2019). Efektivitas Model Pembelajaran POGIL untuk Meningkatkan Kemampuan Pemecahan Masalah pada Materi Garam Menghidrolisis. Jurnal Pendidikan Dan Pembelajaran Kimia, 8(2). https://doi.org/10.23960/jppk.v8.i2.2019 04

Ariani, M., Hamid, A., \& Leny. (2015). Meningkatkan Keterampilan Proses Sains dan Hasil Belajar Siswa Pada Materi Koloid dengan Model Inkuiri Terbimbing (Guided Inquiry) Pada Siswa Kelas XI IPA 1 SMA Negeri 11 Banjarmasin. Quantum (Jurnal Inovasi Pendidikan Sains), 6(1), 98-107. http://ppjp.unlam.ac.id/journal/index.ph p/quantum/article/view/3242

Aydin, A. (2013). Representation of Science Process Skills in the Chemistry Curricula for Grades 10, 11 and 12 / Turkey. International Journal of Education and Practice, 1(5), 51-63. https://doi.org/10.18488/journal.61/2013 $.1 .5 / 61.5 .51 .63$

Dewi, F., Afrida, \& Efrianto, B. (2018). Analisis Keterlaksanaan Pendekatan Experiential Learning dan Pengaruhnya Terhadap Keterampilan Proses Sains Siswa pada Materi Ikatan Kimia di Kelas X MIA SMAN 1 Kota Jambi. Journal of The Indonesia Society of Integrated Chemistry, 10(1), 1-5. https://doi.org/https://doi.org/10.22437/j isic.v10i1.5307

Fitriana, F., Kurniawati, Y., \& Utami, L. (2019). Analisis Keterampilan Proses Sains Peserta Didik Pada Materi Laju Reaksi Melalui Model Pembelajaran Bounded Inquiry Laboratory. JTK 


\footnotetext{
Agustyna Widyaningrum dan Rudiana Agustini

Jurnal Inovasi Pembelajaran Kimia (Journal Of Innovation in Chemistry Education) Volume 3, Nomor 1, April 2021

Analisis Keterampilan Proses Sains Peserta Didik Pada Materi lkatan Kimia Kelas X SMAN 6 Madiun
}

(Jurnal Tadris Kimiya), 4(2), 226-236. https://doi.org/10.15575/jtk.v4i2.5669

Gabby, S., Avargil, S., Herscovitz, O., \& Dori, Y. J. (2017). The case of middle and high school chemistry teachers implementing technology: using the concerns-based adoption model to assess change processes. Chemistry Education Research and Practice, 18(1), 214-232. https://doi.org/10.1039/c6rp00193a

Hafshoh Dwi Nirwana, Sri Haryani, dan S. S. (2016). PENERAPAN PRAKTIKUM BERBASIS MASALAH UNTUK MENINGKATKAN KETERAMPILAN PROSES SAINS SISWA. Jurnal Inovasi Pendidikan Kimia, 6(2), 47-56.

Juhji. (2016). Peningkatan Keterampilan Proses Sains Siswa Melalui Pendekatan Inkuiri Terbimbing. Jurnal Penelitian Dan Pembelajaran IPA, 2(1), 58-70.

Laksana, D. N. L. (2017). the Effectiveness of Inquiry Based Learning for Natural Science Learning in Elementary School. Journal of Education Technology, 1(1), 1. https://doi.org/10.23887/jet.v1i1.10077

Limatahu, I., \& Mubarok, H. (2020). IJORER: International Journal of Recent Educational Education CCDSR Learning Model: Innovation in Physics Learning CCDSR Learning Model: Innovation in Physics Learning. April.

Malik, A., Oktaviani, V., Handayani, W., \& Chusni, M. M. (2017). Penerapan Model Process Oriented Guided Inquiry Learning (POGIL) untuk Meningkatkan Keterampilan Berpikir Kritis Peserta Didik. Jurnal Penelitian \& Pengembangan Pendidikan Fisika, 3(2), 127-136.

https://doi.org/10.21009/1.03202

Rahmadhani, P., \& Novita, D. (2018). Keterampilan Berpikir Kritis Siswa Pada Materi. Jurnal Pembelajaran Kimia, 3(2), 19-30.

Riduwan. 2011. Skala Pengukuran Variabel- variabel Penelitian. Bandung: Alfabeta.

Yuliati, Y. (2016). Peningkatan Keterampilan Proses Sains Siswa Sekolah Dasar Melalui Model Pembelajaran Berbasis Masalah. Jurnal Cakrawala Pendas, 2(2).

https://doi.org/10.31949/jcp.v2i2.335 